\title{
THE VISUAL ACUITY OF THE CORAL FISH MICROCANTHUS STRIGATUS (CUVIER \& VALENCIENNES)
}

\author{
$\operatorname{AUTHOR}(\mathrm{S})$ : \\ Yamanouchi, Toshihiko
}

\section{CITATION:}

Yamanouchi, Toshihiko. THE VISUAL ACUITY OF THE CORAL FISH MICROCANTHUS STRIGATUS (CUVIER \& VALENCIENNES). PUBLICATIONS OF THE SETO MARINE BIOLOGICAL LABORATORY 1956, 5(2): 133-156

ISSUE DATE:

1956-06-30

URL:

http://hdl.handle.net/2433/174560

RIGHT: 


\title{
THE VISUAL ACUITY OF THE CORAL FISH MICROCANTHUS STRIGATUS (CUVIER \& VALENCIENNES) ${ }^{13}$
}

\author{
TOSHIHIKO YAMANOUCHI
}

Member of the Educational Committee of Kyoto Prefecture; Formerly Lecturer of Zoology at Kyoto University

With 16 Tables and 10 Text-figures

\section{CONTENTS}

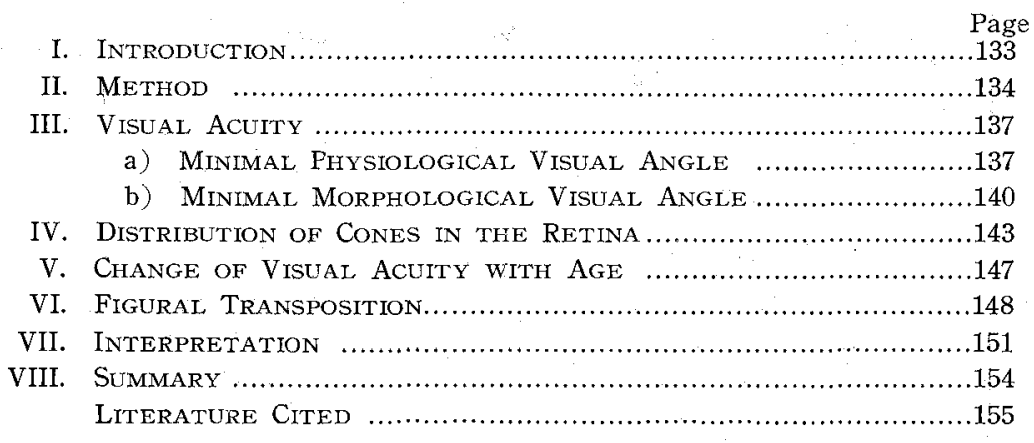

\section{Introduction}

In angling, fine and transparent fishing line is used to render the drail invisible against the bright water background. This proves without a doubt that fish have a keen sight for external objects. Some fish have indeed relatively large eyes in contrast to their size (Fig. 1). In Japan fine and transparent thread made from the silk gland of the Japanese oak-worm moth is used instead of catgut. Recently, drail made from nylon has also been used. Fine drail made from wild-cocoon silk above mentioned is $0.08 \mathrm{~mm}$ in diameter. Whether such fine drail could be seen by fish or not, will be discussed below in VII (Interpretation).

After the pioneer works of HERTER $(1929,1930)$ on the form perception of fish, BRUNNER (1934) studied the visual acuity of the fresh water fish, Phoxinus laevis (Erlitze), by a training method. In his study the limit of visual acuity was determined by training fish to select a fine parallel striped pattern $(+)$ against a gray paper $(-)$ in different light intensities. In this study the coral fish Microcanthus

1) Contributions from the Seto Marine Biological Laboratory, No. 274.

Publ. Seto Mar. Biol. Lab., V (2), 1956. (Article 8) 
strigatus (belonging to Scorpididae) with large eye was adopted as the material. The fish was trained to select one of either a vertically or horizontally striped pattern on the simultaneous presentation of these two figures in water (Fig. 3). This fish showed a keener sight than the Erlitze, as the former has larger eyes than the latter so much, so that the eye axis length of the former is $8 \mathrm{~mm}$, while that of the latter is $2 \mathrm{~mm}$ (BRUNNER, 1934, p. 313).

This study was undertaken during the warm seasons of 1936 and 1937 at the Seto Marine Biological Laboratory of Kyoto University. The preliminary report on the subject has been published in

The visual acuity of fish (in Japanese). Zool. Mag., vol. 48, p. 203, 1936.

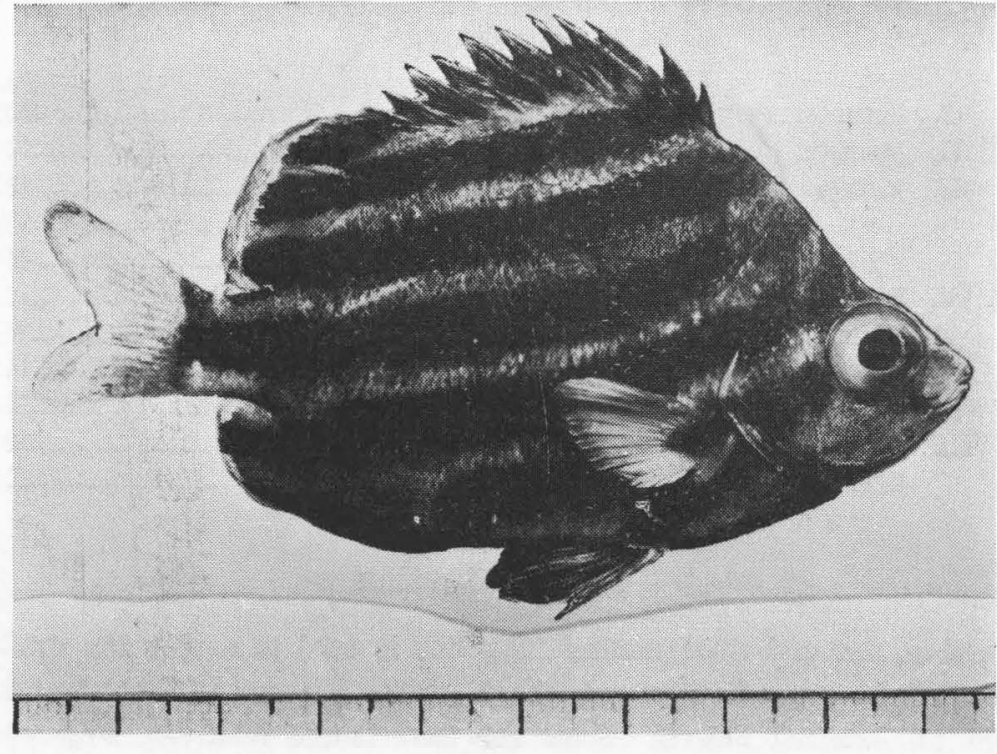

Fig. 1. Microcanthus strigatus. Scale in $\mathrm{cm}$.

$\times 1$

\section{Method}

The fish used for experiment was the coral fish Microcanthus strigatus (Cuvier et Valenciennes), in Japanese called "Kagokakidai." The fish has a body length of about $20 \mathrm{~cm}$ in full growth, and has seven dark colored striations along the body axis on a lemon yellow background (Fig. 1). Fish having a body length of from 9 to $11 \mathrm{~cm}$ were chosen for the experiment.

Each fish was kept alone in a wooden aquarium of the size $72.5 \mathrm{~cm}$ (length), $27.3 \mathrm{~cm}$ (width) and $24 \mathrm{~cm}$ (depth). The water level was kept $16.5 \mathrm{~cm}$ from the bottom (Fig. 2). On one end of the aquarium two rectanglar figures of $2.5 \times 2.5 \mathrm{~cm}$ were simultaneously presented in sea water, each separated $5 \mathrm{~cm}$ apart by black painted wooden board (Fig. 3A). Behind the figure a small piece of cooked lobster 
The Visual Acuity of the Coral Fish
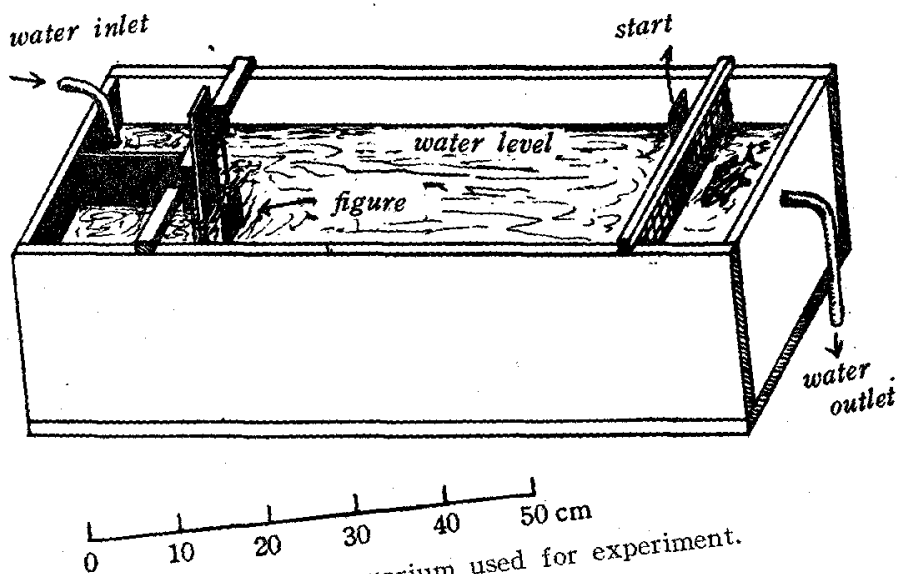

Fig. 2. The aquarium used for ext

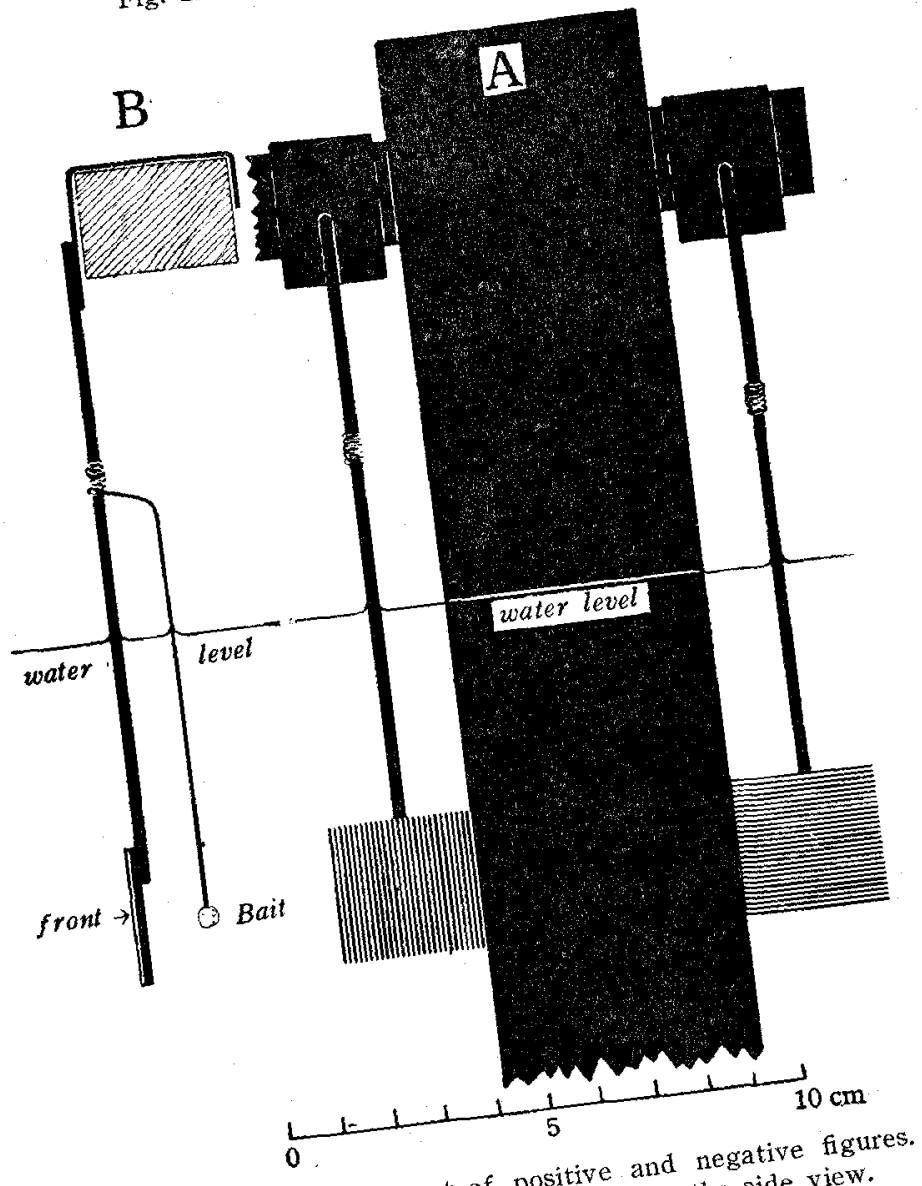

Fig. 3. Arrangement of positive and $B$ the side view. 
meat was attached as bait to the end of a wire; one piece was loosely attached behind the positive figure while the other was firmly fastened by melted paraffine behind the negative figure (Fig. 3B). In training, the fish was confined in the starting chamber at the other end of the aquarium, and then the metal plate on the entrance of the chamber was raised. The fish dashed to the figure and tried to obtain the bait on the back side of the figure. At first rough striped figures were used as training figures, and when these patterns were mastered in selecting correct figure (one of the horizontally and vertically striped figures), a finer striped figure was presented for further training. In testing, the bait was loosely attached for both figures. This method was, however, by no means absolutely good. If the fish once had learned to select bait by figural difference, this method was excellent. If the fish had once learned to take eatable bait not by figural difference but by a difference in the bait itself, further training was totally in vain. An unclever fish, so to speak, deceived by the experimental mechanism, yielded desirable results for the experimenter. In the course of training some fish showed occasionally the tendency to select the figure repeatedly from one definite side of the aquarium independently of the difference of figural pattern. Therefore the position of the two figures should have been changed at random in each trial of training or in the test.

Table 1. Width of black and white stripes.

\begin{tabular}{c|c|c|c}
\hline No. of figure & $\begin{array}{c}\text { Number of black lines } \\
\text { in 25 mm }\end{array}$ & $\begin{array}{c}\text { Number of black and } \\
\text { white lines in 10 cm }\end{array}$ & $\begin{array}{c}\text { Width of black or } \\
\text { white lines in mm }\end{array}$ \\
\hline 1 & 1 & 10.94 & 9.14 \\
2 & 2 & 18.08 & 5.53 \\
3 & 4 & 27.88 & 3.59 \\
4 & 5 & 36.62 & 2.73 \\
5 & 7 & 51.28 & 1.95 \\
6 & 10 & 71.43 & 1.40 \\
7 & 13 & 95.50 & 1.05 \\
\hline 8 & 19 & 137.9 & 0.73 \\
9 & 22 & 160.0 & 0.63 \\
10 & 27 & 172.2 & 0.52 \\
11 & 33 & 239.8 & 0.42 \\
12 & 40 & 298.5 & 0.34 \\
13 & 57 & 420.0 & 0.24 \\
\hline 14 & 82 & 611.1 & 0.16 \\
15 & 107 & 789.0 & 0.13 \\
16 & 135 & 1000 & 0.10 \\
17 & 165 & 1209 & 0.083 \\
18 & 196 & 1429 & 0.077 \\
19 & 228 & 1667 & 0.060 \\
20 & 270 & 1964 & 0.051 \\
\hline
\end{tabular}


Preparation of the figures. 263 equidistant parallel lines were engraved with a diamond pencil on a rectanglar bronze plate $(9.3 \times 9.3 \mathrm{~cm})$; and this bronze grating was printed on paper. The printed striped pattern was reduced by photograph to the desirable magnitudes. The figures of $2.5 \times 2.5 \mathrm{~cm}$ used in this experiment were made from the printing of the negatives thus prepared (Figs. 14-20 in Table 1). The figures of rougher stripes (Figs. $1-13$ in Table 1) were prepared by photography from carefully handdrawn equidistant parallel lines on drawing paper.

\section{Visual Acuity}

\section{a. Minimal physiological visual angle}

The training of fish to discriminate the horizontally and vertically striped figures was started at first with relatively roughly striped figures. In many cases it was began with the figure No. 9 described in Table 1 (width of black or white stripe $0.4 \mathrm{~mm}$ ). When the training was proved to be completed by test, further training was continued with the finer patterns (No. 12,14,16, 18 and finally 20). When the finer figures were first presented, the fish could not discriminate them at first. Further training was required to master the new condition.

Under day light or under bright incandescent illumination, the limit of the fineness of parallel striation discriminated by the fish lay between figures No. 18 and No. 20 (width of black or white striation $0.077 \mathrm{~mm}$ and $0.051 \mathrm{~mm}$ respectively).

Relation between visual acuity and illumination. The experiment to determine the above relation was accomplished under conditions of varied illumination. From 0.1 to 423 Lux illuminated conditions were prepared by electric lamp arrangement. The upper and four sides of the aquarium were surrounded by thin and opaque paper to diffuse the electric light from above. The result is presented in Table 2 and in Fig. 4.

The curve plotted in Fig. 4 indicates clearly the role played by the cones in vision under illumination brighter than 5 Lux. Under illumination below 0.4 Lux the rods seems to play the principal part in figural discrimination. In the transitory phase under illumination between 5 and 0.4 Lux, the vision would depend on both the cones and the rods.

Calculation of the physiological visual angle based on experiment. The visual angle may be calculated by the minimal width of striation discriminated and the eye distance from the figure when the fish has seen the object distinctly. Of course the distance of discrimination is dependent on the width of striation. The coarse pattern may be discriminated at a greater distance than the finer ones. However, it is a well known fact that fish are normally myopic. As Tables 3 and 4 indicate, the fish sees the object at a definite distance from the figures relatively independent of the width of striation. At the point of apparent discrimination of the two figures, the course of swimming turned to one of the two figures. The distance of this turning point of 
Table 2. Minimum width $(d)$ of parallel stripes discriminated by four fish (No. 6, 1, 2, 4) under different illuminations.

\begin{tabular}{c|c|c|c|c|c|c|c|c|c}
\hline $\begin{array}{c}\text { Illumination } \\
I \text { in Lux }\end{array}$ & $\log I$ & \multicolumn{2}{|c|}{ Width $(d)$ of stripe in mm } & $\begin{array}{c}\text { Mean } d \\
\text { in mm }\end{array}$ & $1 / d$ & $\begin{array}{c}\text { Visual angle } \\
d / 40 \mathrm{~mm}\end{array}$ \\
\cline { 4 - 9 } & No. 6 & No. 1 & No. 2 & No. 4 & & \\
\hline 423 & 2.63 & 0.051 & 0.051 & 0.051 & 0.077 & 0.058 & 17.4 & $4^{\prime} 59^{\prime \prime}$ \\
282 & 2.46 & 0.051 & 0.051 & 0.051 & 0.077 & 0.058 & 17.4 & $4^{\prime} 59^{\prime \prime}$ \\
104 & 2.02 & 0.083 & 0.083 & 0.077 & 0.100 & 0.086 & 11.6 & $7^{\prime} 25^{\prime \prime}$ \\
39.6 & 1.60 & 0.164 & 0.127 & 0.164 & 0.237 & 0.146 & 6.85 & $12^{\prime} 43^{\prime \prime}$ \\
11.0 & 1.04 & 0.237 & 0.164 & 0.164 & 0.237 & 0.201 & 4.98 & $17^{\prime}$ \\
\hline 5.0 & 0.70 & 0.237 & 0.237 & 0.237 & 0.237 & 0.237 & 4.22 & $20^{\prime}$ \\
2.2 & 0.34 & 0.237 & 0.237 & 0.237 & 0.237 & 0.237 & 4.22 & $20^{\prime}$ \\
0.4 & -0.40 & 0.237 & 0.237 & 0.237 & 0.237 & 0.237 & 4.22 & $20^{\prime}$ \\
\hline 0.3 & -0.52 & 0.335 & 0.335 & 0.335 & 0.335 & 0.335 & 2.99 & $30^{\prime}$ \\
0.1 & -1.00 & 0.417 & 0.417 & 0.417 & 0.417 & 0.417 & 2.39 & $36^{\prime}$ \\
\hline
\end{tabular}

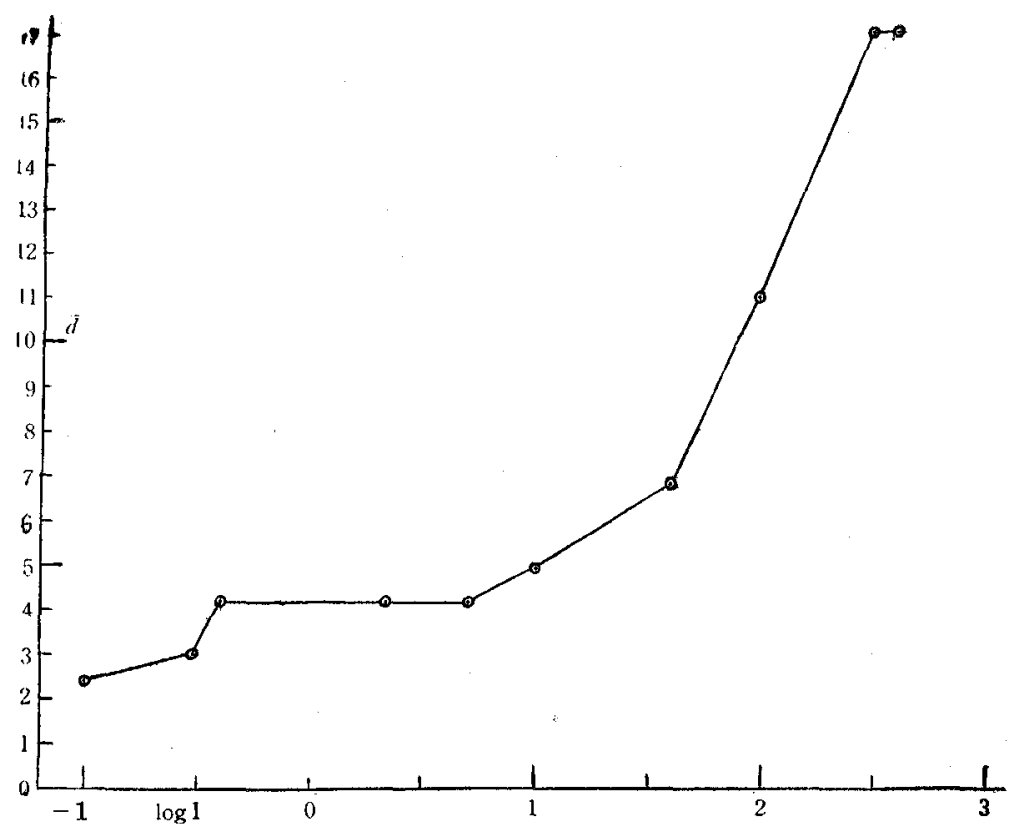

Fig. 4. The relation between visual acuity $(1 / d)$ and illumination. Plotted from the data in Table $\$ 2$. 
Table 3. The number of cases in which the fish apparently discrimitated the simultaneously presented figures at different distances. Under illumination lower than 11 Lux.

\begin{tabular}{|c|c|c|c|c|c|c|c|c|c|c|c|}
\hline \multirow{2}{*}{$\begin{array}{l}\text { Distance from } \\
\text { figure in } \mathrm{cm}\end{array}$} & \multicolumn{10}{|c|}{ No. of figure and the width of striation in $\mathrm{mm}$} & \multirow{2}{*}{ Sum } \\
\hline & \multicolumn{10}{|c|}{ No. $11 \mid$ No. $12 \mid$ No. $13 \mid$ No. $14 \mid$ No. $15 \mid$ No. $16 \mid$ No. $17 \mid$ No. $18 \mid$ No. $19 \mid$ No. 20} & \\
\hline 1 & - & - & - & - & - & - & - & - & - & - & 0 \\
\hline 2 & 1 & - & - & - & - & 1 & - & - & - & 1 & 3 \\
\hline 3 & 4.5 & 1 & 2 & - & - & 1 & 5 & 4 & - & 1 & 18.5 \\
\hline 4 & 9.5 & 3 & 7 & 1 & 1 & - & 8 & 13 & 3 & 8 & 53.5 \\
\hline 5 & 6 & 2 & 9 & 1 & - & 1 & 4 & 5 & 5 & 11 & 44 \\
\hline 6 & 1 & 1 & 15 & 1 & 4 & 7 & 8 & 5 & 2 & 7 & 51 \\
\hline 7 & 1 & - & $\mathbf{1}$ & - & 1 & - & - & 3 & - & 1 & 7 \\
\hline 8 & - & 1 & - & 1 & 2 & 3 & 3 & 3 & - & 3 & 16 \\
\hline 9 & - & - & - & $\ldots$ & - & 2 & - & 4 & - & 1 & 7 \\
\hline 10 & - & - & - & 3 & 3 & 2 & - & 8 & - & 1 & 17 \\
\hline 11 & - & - & - & - & 1 & - & 1 & - & - & 1 & 3 \\
\hline $\begin{array}{l}\text { Mean distadce } \\
\text { in } \mathrm{cm}\end{array}$ & 4.3 & 4.9 & 5.2 & 7.6 & 7.7 & 6.7 & 5.2 & 6.2 & 4.9 & 5.6 & \\
\hline
\end{tabular}

Table 4. The number of cases in which the fish apparently discriminated the simultaneously presented figures at different distances.

\begin{tabular}{|c|c|c|c|}
\hline $\begin{array}{c}\text { Distance from figure } \\
\text { in } \mathrm{cm}\end{array}$ & $\begin{array}{l}\text { Under illumination } \\
\text { lower than } 11 \text { Lux }\end{array}$ & $\begin{array}{l}\text { Under illumination } \\
\text { higher than } 100 \text { Lux }\end{array}$ & Total sum \\
\hline 1 & - & - & 0 \\
\hline 2 & 3 & 1 & 4 \\
\hline 3 & 18.5 & 23 & 41.5 \\
\hline 4 & 53.5 & 116 & 169.5 \\
\hline 5 & 44 & 94 & 138 \\
\hline 6 & 51 & 77.5 & 128.5 \\
\hline 7 & 7 & 67 & 74 \\
\hline 8 & 16 & 31.5 & 47.5 \\
\hline 9 & 7 & 53 & 60 \\
\hline 10 & 17 & & \\
\hline 11 & $3\}$ & 100 & 120 \\
\hline 12 & $-)$ & ) & \\
\hline $14-16$ & - & 38 & 38 \\
\hline $18-20$ & - & 22 & 22 \\
\hline 25 & - & 21 & 21 \\
\hline 30 & - & 18 & 18 \\
\hline 35 & - & 3 & 3 \\
\hline 40 & - & 9 & 9 \\
\hline Sum & 220 & 674 & 894 \\
\hline
\end{tabular}


swimming course and the distance of to and fro swimming plane before the figures indicated the distance of distinct discrimination of the two figures. There were several cases in which the fish discriminated the coarse striped pattern at a distance of $40 \mathrm{~cm}$, but these were rather exceptional. In most cases the discrimination was made at $4 \mathrm{~cm}$ from the figures as Tables 3,4 and Fig. 5 indicate. The visual angle $(\omega)$ is calculated by $\omega=\frac{\text { minimal width of striation }}{\text { distance of distinct discrimination }}$. As indicated in Table 2, fish No. 6, 1 and 2 discriminated figure No. 20 (width of single stripe $0.051 \mathrm{~mm}$ ), then

$$
\omega=0.051 \mathrm{~mm} / 40 \mathrm{~mm}=0.001275=4^{\prime} 23^{\prime \prime}
$$

The average width of striation discriminated by four fish in Table 2 was $0.058 \mathrm{~mm}$ then

$$
\omega=0.058 \mathrm{~mm} / 40 \mathrm{~mm}=0.00145=4^{\prime} 59^{\prime \prime}
$$

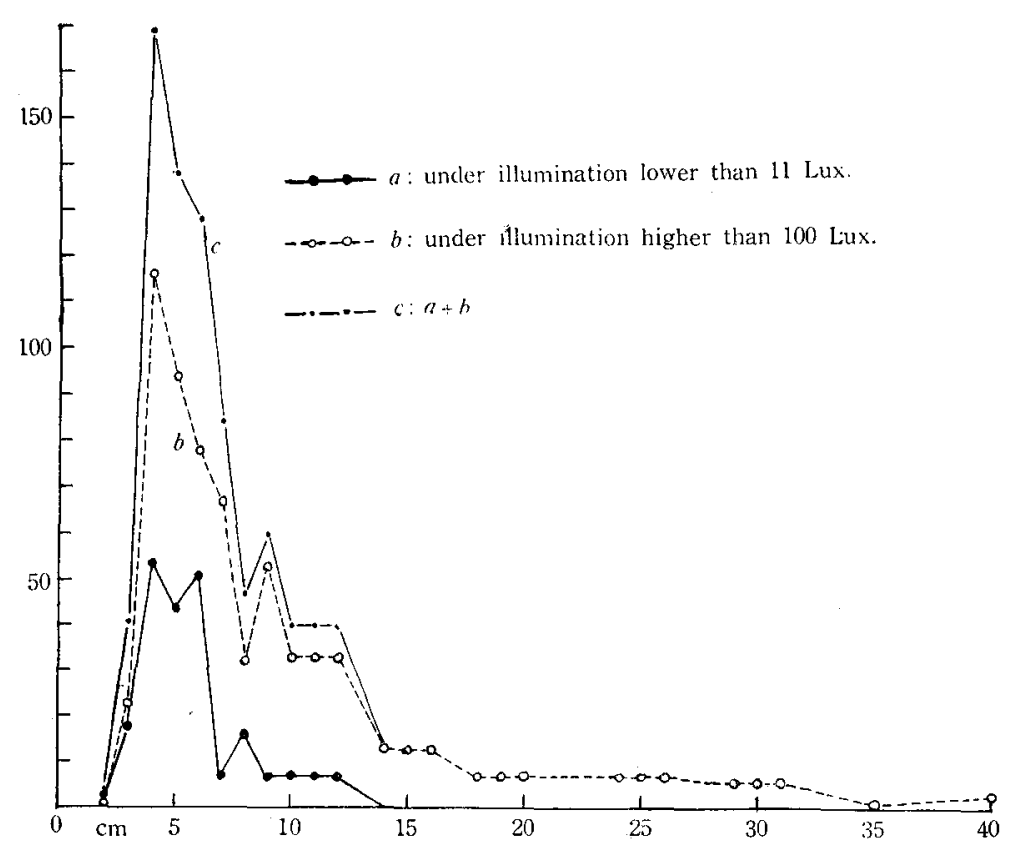

Fig. 5. The frequency of cases in which the fish apparently discriminated the two figures.

\section{b. Minimal morphological visual angle}

The morphological visual angle may be gotten by knowing the mean cone distance in the retina, the refraction index of the sea water and the total refraction index of the lens.

1) Mean distance of cones in the retina. The cones are distributed regularly in the retina, but they are not equidistant. As the direct measurement of their distances 
from each other in microscopic preparation was extremely difficult, it was assumed that the cones were arranged equidistant to each other, or that they were distributed in the center of minute regular hexagon. If $a$ is the side of the regular hexagon, its area is

$$
3 \sqrt{3} / 2=a^{2}
$$

If $d$ is the distance of the two centers of the adjacent hexagon, the distance $(d)$ of each cone is

$$
d=\sqrt{3} a
$$

In the microscopic preparation of the retina dissected parallel to the retinal surface, the number of cones was counted in the rectanglar area of $93 \times 93 \mu$. The area of one cone in the area of $\overline{93 \mu}^{2}$ containing $n$ cones was $(m=93 \mu)$

$$
\frac{m^{2}}{n}=\frac{3 \sqrt{3}}{2} a^{2} \quad \text { or } \quad a=\sqrt{\frac{2}{3 \sqrt{3}}} \cdot \frac{m}{\sqrt{n}}
$$

From (4) and (5)

$$
d=\sqrt{3} a=\sqrt{\frac{2}{\sqrt{3}}} \cdot \frac{m}{\sqrt{n}}=\frac{93}{\sqrt{n}} \cdot \sqrt{\frac{2}{\sqrt{3}}} \quad \text { or } \quad d=\frac{99.93}{\sqrt{n}} \mu
$$

From this relation, if the number $n$ of cones in $\overline{93 \mu}^{2}$ is known, the mean distance of cones in the retina can be estimated. If $n=140$ (Table 7 )

$$
d=99.93 / \mathrm{r} \overline{140}=8.4 \mu
$$

2) Calculation of the total lens refraction index $\left(n_{2}\right)$. MAtThIESSEN (1886) gave the value of $n_{2}$ as 1.6763 in codfish and 1.6476 in carp. The precise value of $n_{2}$ should be measured for each species of fish. In determining the total lens refraction index of Microcanthus strigatus, the following relation for the spherical lens system is expected (Houstoun 1924, p. 44):

$F$ : focal distance of lens

$r:$ radius of lens

$n_{1}:$ refraction index of the sea water (1.339)

$n_{2}:$ total refraction index of lens (unknown)

$m:$ length of eye axis $(F+r)$

$$
\begin{aligned}
& F+r=r \cdot \frac{n_{2}}{2\left(n_{2}-n_{1}\right)}+r=r \cdot \frac{3 n_{2}-2.678}{2\left(n_{2}-1.339\right)} \\
& r \cdot \frac{3 n_{2}-2.678}{2\left(n_{2}-1.339\right)}=m, \quad \text { or } \quad n_{2}=\frac{2.678(m-r)}{2 m-3 r}
\end{aligned}
$$

From the direct measurement of $r$ and $m$ as indicated in Table $5, m-r / 2 m-3 r$ was calculated for fish $3-17 \mathrm{~cm}$ long. This value was practically constant (0.623). From (8)

$$
n_{2}=\frac{2.678(m-r)}{2 m-3 r}=2.678 \times 0.623=1.668
$$


Table 5. Calculation of the total refraction index $\left(n_{2}\right)$ of the fish eye from the radius of lens $(r)$ and the axis of the eye $(m) ; n_{2}=\frac{2.678(m-r)}{2 m-3 r}=2.678 \times 0.623=1.668$.

\begin{tabular}{c|c|c|c|c|c|c|c}
\hline $\begin{array}{c}\text { Body } \\
\text { length in } \\
\text { cm }\end{array}$ & $\begin{array}{c}\text { Mean length } \\
\text { of the radius } \\
\text { of lens }(r) \\
\text { in mm }\end{array}$ & $\begin{array}{c}\text { No. of } \\
\text { specimen }\end{array}$ & $\begin{array}{c}\text { Mean length } \\
\text { of the axis } \\
\text { of eye }(m) \\
\text { in mm }\end{array}$ & $\begin{array}{c}\text { No. of } \\
\text { specimen }\end{array}$ & $\begin{array}{c}m-r \\
\text { in mm }\end{array}$ & $\begin{array}{c}2 m-3 r \\
\text { in mm }\end{array}$ & $\frac{m-r}{2 m-3 r}$ \\
\hline $4-5$ & 1.18 & 2 & 4.07 & 2 & 2.89 & 4.60 & 0.627 \\
$5-6$ & 1.22 & 6 & 4.35 & 6 & 3.13 & 5.04 & 0.620 \\
$6-7$ & 1.36 & 7 & 4.67 & 5 & 3.31 & 5.26 & 0.629 \\
$7-8$ & 1.52 & 1 & 5.50 & 1 & 3.98 & 6.44 & 0.620 \\
$8-9$ & - & - & - & - & - & - & - \\
$9-10$ & 2.09 & 7 & 7.60 & 3 & 5.54 & 8.93 & 0.620 \\
$10-11$ & 2.26 & 7 & 7.95 & 1 & 5.69 & 9.12 & 0.640 \\
$11-12$ & 2.49 & 2 & - & - & - & - & - \\
$12-13$ & 2.52 & 2 & 9.13 & 2 & 6.61 & 10.70 & 0.618 \\
$13-14$ & 2.70 & 5 & - & - & - & - & - \\
$14-15$ & 3.23 & 1 & - & - & - & - & - \\
$15-16$ & 3.34 & 1 & 11.80 & 1 & 8.46 & 13.58 & 0.623 \\
$16-17$ & 3.55 & 3 & 12.10 & 1 & 8.55 & 13.55 & 0.631 \\
\hline
\end{tabular}

3) Relation of minimal physiological and morphological visual angle.

$\omega$ : minimal visual angle measured by experiment $\left(0.001275\right.$ or $\left.4^{\prime} 23^{\prime \prime}\right)$

$\omega^{\prime}$ : morphological visual angle

$n_{1}:$ refraction index of the sea water (1.339)

$n_{2}:$ total refraction index of lens (1.668)

then $\omega^{\prime}=\frac{n_{1}}{n_{2}} \omega=\frac{1.339}{1.668} \omega=0.80 \omega \quad$ From (1) $\omega=\frac{0.051 \mathrm{~mm}}{40 \mathrm{~mm}}=0.001275$ or $4^{\prime} 23^{\prime \prime}$ then $\omega^{\prime}=0.80 \omega=0.80 \times 0.001275=0.00102 \quad$ or $\quad 3^{\prime} 30^{\prime \prime}$

From Fig. 6, $h=b \operatorname{tg} \omega^{\prime}=b \omega^{\prime},\left(\operatorname{tg} \omega^{\prime}=\omega^{\prime}\right)$

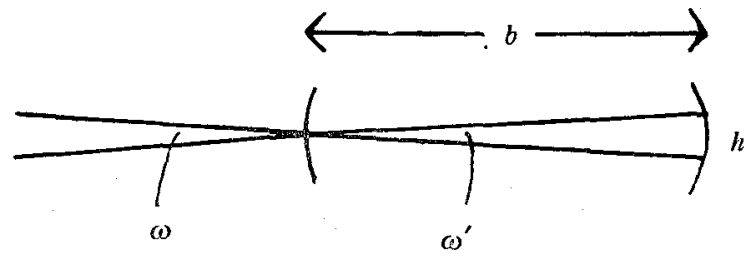

Fig. 6. The schema of the optical system of the eye.

For fish with body lengths of from $10-11 \mathrm{~cm}$, the length of eye axis was from 7.60 to $8.40 \mathrm{~mm}$, or $8 \mathrm{~mm}$ in average value by direct measurement. 
From (10)

$$
h=b \omega^{\prime}=8.00 \times 0.00102 \mathrm{~mm}=8.2 \mu
$$

4) Calculation of morphological visual angle from the mean cones distance. From Table 7 the mean number of cones $(n)$ contained in $\overline{93 \mu}^{2}$ area in the central and back parts of the retina of fish with body lengths of $10-10.8 \mathrm{~cm}$ was 140 . The mean distance of cones is given as already mentioned in (6).

$$
d=\frac{99.93}{\sqrt{n}} \mu=\frac{99.93}{\sqrt{140}} \mu=8.4 \mu
$$

The value of $d$ based on experimental data was $8.2 \mu$ (11) and the value calculated from the mean cone distance was $8.4 \mu$ as above mentioned. Both values practically coincide, allowing the high probable error in experiment and measurement in this type of work.

The minimal morphological visual angle may also be calculated by the length of eye axis and the mean distance of cones as follows:

$$
\omega^{\prime}=8.4 \mu / 8 \mathrm{~mm}=0.00105 \text { or } 3^{\prime} 36^{\prime \prime}
$$

$3^{\prime} 36^{\prime \prime}$ is not a very different value from the $3^{\prime} 30^{\prime \prime}$ theoretically deduced from minimal physiological visual angle (10).

\section{Distribution of Cones in the Retina}

Fish retina was fixed in an alcohol-formalin mixture (2 parts $80 \%$ alcohol plus 1 part $40 \%$ formaldehyde after PETERFI), and the fixed retina was dissected by microtome after paraffine imbedding. Section was made parallel to the retinal surface. 9 parts of the retina were chosen for dissection as indicated in Fig. 7. Microtomic sections
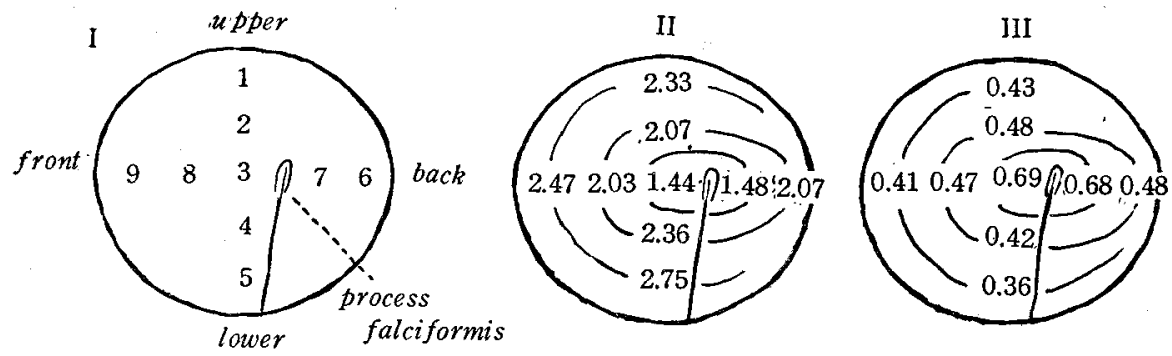

Fig. 7. The retina of Microcanthus strigatus enlarged.

I. 9 parts of the retina dissected.

II. The ratio of the number of cones/ganglion cells as indicated in Table 10.

III. Reciprocal of the above as in Table 10 .

were stained by HEIDENHEIN's hematoxylin and eosin. The cones were stained pink red, and the ganglion cells blue violet. The number of cones and ganglion cells were counted in an area $93 \times 93 \mu$. In Table 6 is presented the number of cones in 9 parts of the retina of this fish with body lengths from 9.4 to $16.5 \mathrm{~cm}$. 
Table 6. The number and the mean distance of cones in the area of $\overline{93 \mu}^{2}$ in the different sections of retina.

\begin{tabular}{|c|c|c|c|c|c|c|c|c|c|c|c|c|}
\hline \multirow{2}{*}{ Specimen } & \multirow{2}{*}{$\begin{array}{l}\text { Body } \\
\text { length } \\
\text { in } \mathrm{cm}\end{array}$} & \multicolumn{9}{|c|}{ Part of the retina } & \multirow{2}{*}{$\begin{array}{l}\text { Mean } \\
\text { num- } \\
\text { ber }\end{array}$} & \multirow{2}{*}{$\begin{array}{l}\text { Mean } \\
\text { distance } \\
\text { in } \mu\end{array}$} \\
\hline & & 1 & 2 & 3 & 4 & 5 & 6 & 7 & 8 & 9 & & \\
\hline C & 9.4 & 76 & 93 & 156.6 & 90.5 & 100 & 141.5 & 171.5 & 80 & 114 & 113.5 & 9.4 \\
\hline b & 10 & 61 & 80.5 & 134.5 & 87.5 & 96 & 136 & 175 & 121 & 91 & 109.2 & 9.6 \\
\hline i & 10.3 & 66 & 67 & 120.5 & 81 & 80 & 141.5 & 100 & 99 & 94 & 94.3 & 10.3 \\
\hline $\mathrm{B}$ & 10.4 & 58 & 79.5 & 163 & 77 & 72.5 & 182.5 & 157.5 & 86 & 87.5 & 85.9 & 10.2 \\
\hline $\mathrm{d}$ & 10.4 & 64 & 74.5 & 137 & 85 & 96.5 & 147 & 162 & 101 & 124 & 110.1 & 9.5 \\
\hline $\mathrm{k}$ & 10.8 & 70.8 & 62 & 102 & 83.5 & 79 & 128 & 128 & 85 & 81 & 91 & 10.5 \\
\hline W & 10.8 & 67.5 & 54 & 107 & 73 & 73.5 & 119.5 & 100.5 & 102.5 & 84.5 & 86.9 & 10.7 \\
\hline \multicolumn{2}{|c|}{$\begin{array}{l}\text { Mean number of } \\
\text { cones }\end{array}$} & 66.2 & 72.9 & 131.5 & 82.5 & 85.4 & 142.3 & 142.1 & 96.4 & 96.6 & 100.1 & \\
\hline \multicolumn{2}{|c|}{$\begin{array}{l}\text { Mean distance of } \\
\text { cones calculated } \\
\text { from } \frac{99.93}{\sqrt{n}} \text { in } \mu\end{array}$} & 12.2 & 11.7 & 8.7 & 11.0 & 10.8 & 8.4 & 8.4 & 10.2 & 10.2 & & 10.0 \\
\hline Specimen & $\begin{array}{l}\text { Body } \\
\text { length }\end{array}$ & 1 & 2 & 3 & 4 & 5 & 6 & 7 & 8 & 9 & $\begin{array}{l}\text { Mean } \\
\text { num- } \\
\text { ber }\end{array}$ & $\begin{array}{c}\text { Mean } \\
\text { distance }\end{array}$ \\
\hline 3 & 12.3 & 50.5 & 54.5 & 136.5 & 60.5 & 62.5 & 82.5 & 88 & 68.5 & 63 & 74.1 & 11.6 \\
\hline 4 & 13.0 & 45 & 52 & 102.5 & 64 & 51 & 86.5 & 122 & 83.5 & 69 & 75.1 & 11.5 \\
\hline $\mathrm{n}$ & 13.6 & 46.8 & 57 & 79.5 & 53.3 & 59 & 110.3 & 106 & 75.5 & 80.5 & 74.3 & 11.6 \\
\hline $\mathrm{m}$ & 13.9 & 43.5 & 42.5 & 95 & 49 & 74 & 83 & 89.5 & 82.5 & 63 & 69.1 & 12.0 \\
\hline \multicolumn{2}{|c|}{$\begin{array}{l}\text { Mean number of } \\
\text { cones }\end{array}$} & 46.5 & 51.5 & 103.4 & 56.7 & 61.6 & 90.6 & 101.4 & 77.6 & 68.9 & 73.2 & \\
\hline \multicolumn{2}{|c|}{$\begin{array}{l}\text { Mean distance } \\
\text { of cones in } \mu\end{array}$} & 14.7 & 13.9 & 9.8 & 13.3 & 12.7 & 10.5 & 9.9 & 11.3 & 12.0 & & 11.7 \\
\hline Specimen & $\begin{array}{l}\text { Body } \\
\text { length }\end{array}$ & 1 & 2 & 3 & 4 & 5 & 6 & 7 & 8 & 9 & $\begin{array}{l}\text { Mean } \\
\text { num- } \\
\text { ber }\end{array}$ & $\begin{array}{l}\text { Mean } \\
\text { distance }\end{array}$ \\
\hline 21 & 15.3 & 一 & 37 & 71.5 & 44.5 & - & 54 & 68 & 64.5 & 38 & 53.9 & 13.5 \\
\hline 22 & 16.5 & 32 & 41.5 & 65 & 32.5 & 29 & 53 & 54 & 66 & 76.5 & 49.9 & 14.3 \\
\hline 25 & 16.5 & 23 & 24 & 66.5 & 30.5 & 33 & 61.5 & 66.5 & 44.5 & 38 & 43.1 & 15.2 \\
\hline \multicolumn{2}{|c|}{$\begin{array}{c}\text { Mean number of } \\
\text { cones }\end{array}$} & 27.5 & 34.2 & 67.7 & 32.5 & 31 & 56.2 & 62.8 & 58.3 & 50.8 & 49.3 & \\
\hline \multicolumn{2}{|c|}{$\begin{array}{l}\text { Mean distance of } \\
\text { cones in } \mu\end{array}$} & 19.1 & 17.1 & 12.1 & 17.5 & 18.0 & 13.3 & 12.6 & 13.1 & 14.0 & & 14.3 \\
\hline
\end{tabular}

The cones are distributed more densely in the center or bottom of the eye (Table 6) and in the outer or back part of the retina than the other parts. Hence they are smaller in size than the other parts. With the growth of fish the cones in a definite area of the retina decrease in number and increase in size. The mean distance of cones in the whole retina vary from $10.0 \mu, 11.7 \mu$ and $14.3 \mu$ correspondingly with the size of fishes $9.4-10.8 \mathrm{~cm}, 12.3-13.9 \mathrm{~cm}$ and $15.3-16.5 \mathrm{~cm}$.

In Table 7 is shown the density and the mean distance of cones in the central 
Table 7. The number and mean distance of cones in $\overline{93 \mu}^{2}$ in the central (3) and back (outer 6,7 ) part of retina.

\begin{tabular}{c|c|c|c|c|c}
\hline \hline \multirow{2}{*}{ Specimen } & $\begin{array}{c}\text { Body length } \\
\text { in cm }\end{array}$ & \multicolumn{3}{|c|}{ Part of retina } & Mean \\
\cline { 2 - 5 } & 10 & 3 & 6 & 7 & 154.5 \\
$\mathrm{a}$ & 10 & 168.5 & 141.5 & 154 & 152.5 \\
$\mathrm{c}$ & 10 & 135 & 173.5 & 175 & 131.3 \\
$\mathrm{i}$ & 10.3 & 120.5 & 151 & 108 & 120.5 \\
$\mathrm{~h}$ & 10.3 & 128 & 186.5 & 151 & 158.5 \\
$\mathrm{~d}$ & 10.4 & 137 & 147.5 & 162 & 148.8 \\
$\mathrm{f}$ & 10.4 & 150.5 & 127.5 & 135 & 137.7 \\
$\mathrm{~B}$ & 10.4 & 163 & 182.5 & 157.5 & 167.7 \\
$\mathrm{k}$ & 10.8 & 102 & 128.5 & 128 & 119.3 \\
$\mathrm{I}$ & 10.8 & 107 & 119.5 & 105 & 110.5 \\
\hline \multicolumn{2}{c|}{ Mean number of cones } & 132 & 150 & 138 & 140 \\
\hline Mean distance of cones in $\mu$ & 8.7 & 8.2 & 8.5 & 8.4 \\
\hline
\end{tabular}

and the back part of the retina where the density of cones was highest $(3,6,7$ in Fig. $7 \mathrm{I})$ of such size of fish as used in the experiment $(10-11 \mathrm{~cm} \mathrm{long})$. In these parts of the retina there existed $140(n)$ cones in $\overline{93 \mu}^{2}$ area and mean distance of them was $8.4 \mu$. In Tables 8,9 and 10 the relation between the density of the cones and the ganglion cells directly connected with the cones is shown as the result of measurement of the dissected materials. This relation is shown in Fig. 7 II, III. In the central (3) and the rear adjacent region (7), the number of cones per 1 ganglion cells is minimal (II in Fig. 7) or the number of ganglion cell per 1 cone is maximal (III in Fig. 7).

Table 8. Number of cones in $\overline{93 \mu}^{2}$ area in different parts of the retina.

\begin{tabular}{|c|c|c|c|c|c|c|c|c|c|c|}
\hline \multirow{2}{*}{$\begin{array}{l}\text { Speci- } \\
\text { men }\end{array}$} & \multirow{2}{*}{$\begin{array}{l}\text { Body } \\
\text { length } \\
\text { in } \mathrm{cm}\end{array}$} & \multicolumn{9}{|c|}{ Part of retina } \\
\hline & & 1 & 2 & 3 & 4 & 5 & 6 & 7 & 8 & 9 \\
\hline $\mathrm{C}$ & 9.4 & 76 & 93.5 & 156.5 & 90.5 & 100 & 141.5 & 171.5 & 80 & 114 \\
\hline $\mathrm{N}$ & 10 & 61 & 80.5 & 134.5 & 87.5 & 96 & 136 & 175 & 121 & 91 \\
\hline $\mathrm{Q}$ & 10.3 & 74.5 & 63.5 & 121.5 & 80.5 & 80 & 109.5 & 92.5 & 82.5 & 85 \\
\hline $\mathrm{R}$ & 10.3 & 57 & 70.5 & 119.5 & 81.5 & 80.5 & 173.5 & 108 & 115.5 & 102.5 \\
\hline B & 10.4 & 58 & 79.5 & 163 & 77 & 72.5 & 182.5 & 157.5 & 86 & 87.5 \\
\hline$P$ & 10.4 & 64 & 67 & 130.5 & 78 & 87 & 154.5 & 165 & 115 & 135.5 \\
\hline A & 10.8 & 58 & 55 & 85 & 80.5 & 82 & 141.5 & 133 & 86 & 86 \\
\hline $\mathrm{G}$ & 10.8 & 83.5 & 68.5 & 119 & 86.5 & 75.5 & 115 & 123.5 & 84.5 & 76.5 \\
\hline $\mathrm{W}$ & 10.8 & 67.5 & 54 & 107 & 73 & 73.5 & 119.5 & 100.5 & 102.5 & 84.5 \\
\hline $\mathbf{J}$ & 12.5 & 50.5 & 54.5 & 136.5 & 60.5 & 62.5 & 82.5 & 88 & 68.5 & 63 \\
\hline I & 13 & 45 & 52 & 102.5 & 64 & 51 & 86.5 & 122 & 83.5 & 69 \\
\hline
\end{tabular}


Table 9. Number of ganglion cells in $\overline{93 \mu}^{2}$ area in different parts of the retina.

\begin{tabular}{|c|c|c|c|c|c|c|c|c|c|c|}
\hline \multirow{2}{*}{$\begin{array}{l}\text { Speci- } \\
\text { men }\end{array}$} & \multirow{2}{*}{$\begin{array}{l}\text { Body } \\
\text { length } \\
\text { in } \mathrm{cm}\end{array}$} & \multicolumn{9}{|c|}{ Part of retina } \\
\hline & & 1 & 2 & 3 & 4 & 5 & 6 & 7 & 8 & 9 \\
\hline C & 9.4 & 33 & 46.8 & 94 & 35 & 39.4 & 75.6 & 135 & 41.1 & 47.3 \\
\hline $\mathrm{N}$ & 10 & 31 & 34 & 94 & 30 & 36 & 65.9 & 94 & 70.5 & 47.3 \\
\hline Q & 10.3 & 30.2 & 33 & 85 & 36.8 & 26 & 52 & 49.5 & 40.5 & 33 \\
\hline $\mathrm{R}$ & 10.3 & 27 & 36 & 101.7 & 49.5 & 24.3 & 70.5 & 88.5 & 54 & 42.3 \\
\hline B & 10.4 & 24.1 & 23.5 & 117.5 & 31.5 & 25.5 & 91.3 & 104.7 & 45.3 & 35.4 \\
\hline $\mathrm{P}$ & 10.4 & - & - & 103 & 28.8 & 28 & 70 & 126 & 65 & 56.3 \\
\hline A & 10.8 & 31 & 27 & 70.2 & 28 & 33 & 78.8 & 98 & 45 & 30.2 \\
\hline G & 10.8 & 30.8 & 30.8 & 77.3 & 50.6 & 29.4 & 49.9 & 81 & 36.1 & 37.8 \\
\hline $\mathrm{W}$ & 10.8 & 25.5 & 31.5 & 63 & 34 & 25.1 & 57 & 69.8 & 45 & 32 \\
\hline $\mathrm{J}$ & 12.5 & 21.7 & 24.6 & 96 & 27.5 & 27 & 44.4 & 54.3 & 29.2 & 29.5 \\
\hline I & 13 & 22 & 23 & 64 & 25 & 23 & 42 & 90 & 43.5 & 22 \\
\hline
\end{tabular}

Table 10. Ratio of the number of cones/ganglion cells in different parts of the retina.

\begin{tabular}{c|c|c|c|c|c|c|c|c|c|c}
\hline \multirow{2}{*}{$\begin{array}{c}\text { Speci- } \\
\text { men }\end{array}$} & $\begin{array}{c}\text { Body } \\
\text { length } \\
\text { in cm }\end{array}$ & \multicolumn{10}{|c|}{ Part of retina } \\
\cline { 2 - 9 } C & 9.4 & 2.30 & 1.56 & 1.66 & 2.59 & 2.54 & 1.87 & 1.26 & 1.94 & 2.61 \\
$\mathrm{~N}$ & 10 & 1.97 & 2.37 & 1.43 & 2.91 & 2.67 & 2.06 & 1.86 & 1.72 & 1.92 \\
$\mathrm{Q}$ & 10.3 & 2.47 & 1.91 & 1.43 & 2.18 & 3.08 & 2.10 & 1.87 & 2.04 & 2.55 \\
$\mathrm{R}$ & 10.3 & 2.11 & 1.96 & 1.17 & 1.65 & 3.30 & 2.06 & 1.22 & 2.14 & 2.42 \\
$\mathrm{~B}$ & 10.4 & 1.78 & 2.41 & 1.39 & 2.44 & 2.84 & 2.01 & 1.50 & 1.90 & 2.47 \\
$\mathrm{P}$ & 10.4 & - & - & 1.26 & 2.71 & 3.10 & 2.21 & 1.31 & 1.77 & 2.41 \\
$\mathrm{~A}$ & 10.8 & 1.87 & 2.04 & 1.21 & 2.87 & 2.71 & 1.81 & 1.36 & 1.91 & 2.85 \\
$\mathrm{G}$ & 10.8 & 3.75 & 2.23 & 1.54 & 1.73 & 2.57 & 2.30 & 1.52 & 2.34 & 2.03 \\
$\mathrm{~W}$ & 10.8 & 2.65 & 1.71 & 1.70 & 2.15 & 2.93 & 2.07 & 1.44 & 2.28 & 2.64 \\
$\mathrm{~J}$ & 12.5 & 2.33 & 2.22 & 1.42 & 2.20 & 2.31 & 1.86 & 1.62 & 2.34 & 2.14 \\
$\mathrm{I}$ & 13 & 2.05 & 2.26 & 1.60 & 2.56 & 2.22 & 2.06 & 1.35 & 1.92 & 3.14 \\
\hline
\end{tabular}

Although there is morphologically no clear Fovea in this fish, there is a region of relatively broad extension where the image of external object should be formed most accurately compared with the other regions of the retina as shown in II, III of Fig. 7. It is an interesting fact that such an accurately seeing region should be located in the central and rear adjacent region of the retina. The minute structure of the retina is so constructed that the fish is able to see accurately the front part of the head. 


\section{Change of Visual Acuity with Age}

The resolving power of the eye increases with the growth of lens and decreases with the enlargement of adjacent cones distance. A smaller fish has a small eye i.e. small lens, but it has small condensed cones. With the growth of fish the lens increase in diameter but the cone in the retina becomes larger and hence the distance of each cone is enlarged. The change of the visual acuity of fish with age can be tested experimentally, but in this report this point has been made clear morphologically by the measurement of lens diameter and the mean distance of cones (Table 11).

Table 11. Relative visual acuity (S) of the fish calculated from the radius of lens and from the mean distance of cones. The number in bracket denotes the number of specimen.

\begin{tabular}{r|c|c|c|c|c|c|c}
\hline $\begin{array}{c}\text { Body } \\
\text { length } \\
\text { in cm }\end{array}$ & $\begin{array}{c}\text { Mean } \\
\text { radius } \\
\text { in mm } r\end{array}$ & $\begin{array}{c}F=2.54 r^{*} \\
\text { in } \mathrm{mm}\end{array}$ & $\begin{array}{c}F+r=3.54 r \\
\text { in mm }\end{array}$ & $\begin{array}{c}\text { Mean num- } \\
\text { ber of cones } \\
\text { in } \begin{array}{c}932^{2} \\
n\end{array}\end{array}$ & $\begin{array}{c}\text { Mean distance } \\
\text { of cones } \\
d=\frac{99.93}{\sqrt{n}} \mu\end{array}$ & $1 / d$ & $\begin{array}{c}\text { Relative } \\
\text { visual acuity } \\
S=\frac{1}{\omega^{\prime}}=\frac{F+r}{d}\end{array}$ \\
\hline $4-5$ & $1.18(2)$ & 3.00 & 4.18 & $190(3)$ & 7.25 & 0.138 & 0.58 \\
$5-6$ & $1.22(6)$ & 3.10 & 4.32 & $180(6)$ & 7.35 & 0.136 & 0.60 \\
$6-7$ & $1.36(7)$ & 3.45 & 4.81 & $179(7)$ & 7.46 & 0.134 & 0.65 \\
$7-8$ & $1.52(1)$ & 3.86 & 5.38 & $168.5(2)$ & 7.69 & 0.130 & 0.70 \\
$8-9$ & - & - & - & $147.5(2)$ & 8.25 & 0.121 & - \\
$9-10$ & $2.09(7)$ & 5.23 & 7.29 & $149(4)$ & 8.19 & 0.122 & 0.89 \\
$10-11$ & $2.26(7)$ & 5.74 & 8.00 & $137(7)$ & 8.54 & 0.117 & 0.94 \\
$11-12$ & $2.49(2)$ & 6.32 & 8.81 & $115(1)$ & 9.34 & 0.107 & 0.94 \\
$12-13$ & $2.52(2)$ & 6.40 & 8.92 & $103(2)$ & 9.89 & 0.101 & 0.94 \\
$13-14$ & $2.70(5)$ & 6.86 & 9.56 & $94.5(2)$ & 10.3 & 0.097 & 0.93 \\
$14-15$ & $3.23(1)$ & 8.20 & 11.43 & - & - & - & - \\
$15-16$ & $3.34(1)$ & 8.39 & 11.73 & $62.5(2)$ & 12.6 & 0.079 & 0.93 \\
$16-17$ & $3.55(3)$ & 9.02 & 12.57 & $61 \quad(2)$ & 12.8 & 0.078 & 0.98 \\
\hline
\end{tabular}

* For spherical lens $F=\frac{n_{2} r}{2\left(n_{2}-n_{1}\right)}, n_{1}=1.339, n_{2}=1.668$; then $F=2.54 r$.

Morphological visual angle $\left(\omega^{\prime}\right)$ is given by the formula $\omega^{\prime}=\frac{\text { mean distance of cones }}{\text { length of the eye axis }}$ $=\frac{d}{F+r}$ The relative visual acuity $(S)$ of the eye is given as $S=1 / \omega^{\prime}=(F+r) / d$, and is calculated in Table 11. The mean distance of cones was measured in the regions 3,6 and 7 as in Fig. $7 \mathrm{I}$, where the density of cones was greatest. The lens diameter was directly measured from fresh material. The eye axis was calculated by $r$, as $F+r=2.54 r+r=3.54 r$. For spherical lens $F=n_{2} r / 2\left(n_{2}-n_{1}\right), n_{1}=1.339$ (for sea water) and $n_{2}=1.668$ (from Table 5 ); then $F=1.668 \mathrm{r} / 2(1.668-1.339)=1.668 \mathrm{r} / 0.658$ $=2.54 r$. As shown in Fig. 8, the visual acuity of this fish increases with age becoming practically constant when the length of the fish reaches $10 \mathrm{~cm}$ so that the fish in maturity obtains a more accurate image of outer world than the young immature ones. 


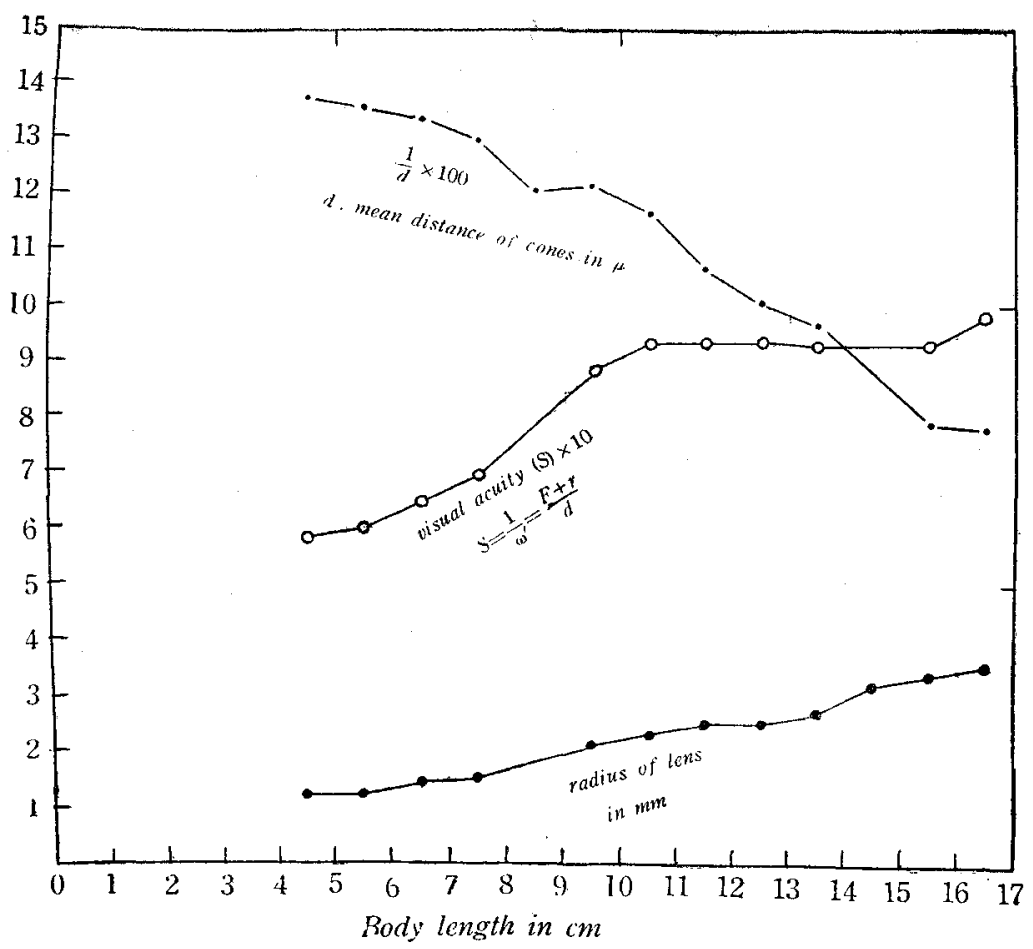

Fig. 8. Change of visual acuity with age.

-...- reciprocal of the mean cone distance.

- - radius of lens.

$-0_{-}-$relative visual acuity $(S)$.

\section{Figural Transposition}

a) When unexperienced equally striped figures presented.

After the fish had been trained to the choice of a vertically striped figure of No. 12 (width of black or white line $0.34 \mathrm{~mm}$ ) as against a horizontally striped figure, figure set No. 1 (width of each stripe $3.6 \mathrm{~mm}$ ) was presented and the fish took bait from the vertically striped figure in spite of the coarser pattern.

b) When unequally striped figures presented.

The fish had been trained to choose the horizontally striped figure No. 12 (width of stripe $0.34 \mathrm{~mm}$ ). After this training, both the horizontally striped figure No. 1 (width of stripe $3.6 \mathrm{~mm}$ ) and vertically striped figure No. 12 (width of stripe $0.34 \mathrm{~mm}$ ) were presented for free choice. The fish chose the rougher striped horizontally striped figure. After this test the relation of the above both figures was reversed (that is, horizontally striped figure No. 12 and vertically striped figure No. 1 were presented). The fish chose the originally trained horizontally striped No. 12 figure. Further tests 
of the same kind and in other figural combinations were carried out with principally the same results. It is clear that, in addition to accurately seeing the striation, the fish were able to distinguish the vertical and horizontal relation of the figural pattern.

c) Absolute and relative selection.

Three sorts of vertically striped rectangular figures $7 \times 7 \mathrm{~cm}$ were prepared (Fig. 9). Five fish had been trained to choose the finer stripe II $(+)$ against the rougher I $(-)$. After training, figures II and III were presented for free choice. Next the same group
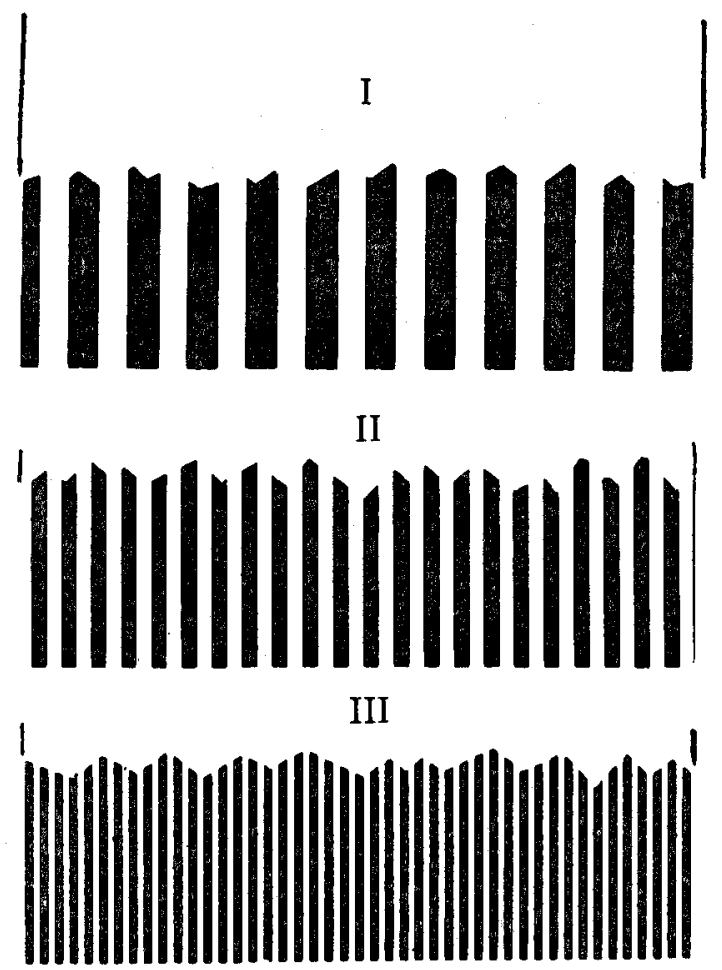

Fig. 9. Lower part of three vertically striped figures $(7 \times 7 \mathrm{~cm})$.

of fish were trained with figures II $(+)$ and III $(-)$. As a test figures I and II were presented.

The two figures were hung in sea water closely side by side. The same eatable bait was attached to the ends of wires hung just in front of the figural centers. At the outer side of each figure, a movable wooden plate was prepared, and when the fish had dashed to the negative or prohibited figure, the wooden plate was suddenly slid by experimeter's hand before the prohibited figure to discourage the fish taking the bait from the negative figure. When the fish took the bait before the positive figure nothing was done. 
Such training was continued from 200 to 400 times over a period of 20 days. At intervals tests were made with a new pair of figures leaving the fish to free choice of the figure.

Table 12. Trained with the figures I $(-)$ and II $(+)$. Test was made with figures II and III. The number indicates the case of relative selection in 10 tests, that is, 10 indicates 10 choices of III, and 0 indicates no choice of III, or 10 choices of II. 5 indicates 5 choices of III in 10 tests.

\begin{tabular}{|c|c|c|c|c|}
\hline \multirow{2}{*}{ No. of fish } & \multicolumn{4}{|c|}{ Number of III selection in test within the trained number of cases } \\
\hline & $\begin{array}{c}\text { Within } \\
100 \text { training }\end{array}$ & 200 & 300 & 400 \\
\hline A & 8 & 10,8 & - & - \\
\hline $\mathrm{B}$ & 2 & 1 & 5,3 & - \\
\hline 1 & 5 & 2 & 4,7 & 5 \\
\hline 2 & 4 & 5 & - & - \\
\hline 3 & 4 & 3 & 0 & 2 \\
\hline
\end{tabular}

Table 13. Trained with figures II $(+)$ and III $(-)$. Test was made with figures I and II. The number indicates the case of relative selection in 10 tests. 7 indicates the selection of $I$ seven times in 10 tests.

\begin{tabular}{c|c|c|c|c}
\hline \multirow{2}{*}{ No. of fish } & \multicolumn{3}{|c|}{ Number of I selection in test within the trained number of cases } \\
\cline { 2 - 5 } & $\begin{array}{c}\text { Within } \\
\text { 100 trainings }\end{array}$ & 200 & 300 & 400 \\
\hline A & - & 3,2 & 5,0 & 5 \\
B & 9 & 5,5 & 6,5 & - \\
1 & 7 & 5 & 5 & 5 \\
2 & - & 7 & 5 & 6,6 \\
3 & 7 & 6 & 6,5 & - \\
\hline
\end{tabular}

Table 14. Arranged from the Tables 12 and 13. Evaluation of the selection numbers given in the above two tables. $0-3$ absolute selection $(a), 4-6$ absolute and relative selection $(a, r), 7-10$ relative selection $(r)$.

\begin{tabular}{|c|c|c|c|c|c|}
\hline \multirow{6}{*}{$\begin{array}{l}\text { From the } \\
\text { Table } 12\end{array}$} & No. of fish & $\begin{array}{c}\text { Within } 100 \\
\text { trainings }\end{array}$ & 200 & 300 & 400 \\
\hline & A & $r$ & $r$ & - & - \\
\hline & $\mathrm{B}$ & $a$ & $a$ & $a, r$ & - \\
\hline & 1 & $a, r$ & $a$ & $a, r$ & $a, r$ \\
\hline & 2 & $a, r$ & $a, r$ & - & - \\
\hline & 3 & $a, r$ & $a$ & $a$ & $a$ \\
\hline \multirow{5}{*}{$\begin{array}{l}\text { From the } \\
\text { Table } 13\end{array}$} & $\mathrm{~A}$ & - & $a$ & $a$ & $a, r$ \\
\hline & $B$ & $r$ & $a, r$ & $a, r$ & - \\
\hline & 1 & $r$ & $a, r$ & $a, r$ & $a, r$ \\
\hline & 2 & - & $r$ & $a, r$ & $a, r$ \\
\hline & 5 & $r$ & $a, r$ & $a, r$ & - \\
\hline
\end{tabular}




\begin{tabular}{l|c|c|c|c} 
(continued) \\
\hline $\begin{array}{l}\text { relative } \\
\text { absolute, relative }\end{array}$ & $4(50 \%)$ & $2(20 \%)$ & - & - \\
absolute & $3(37.5 \%)$ & $4(40 \%)$ & $6(75 \%)$ & $4(80 \%)$ \\
\hline Total cases & $1(12.5 \%)$ & $4(40 \%)$ & $2(25 \%)$ & $1(20 \%)$ \\
\hline * Relative percentage & $8(100 \%)$ & $10(100 \%)$ & $8(100 \%)$ & $5(100 \%)$ \\
$*$ Absolute percentage & $69 \%$ & $40 \%$ & $37.5 \%$ & $40 \%$ \\
\hline
\end{tabular}

* The percentage of absolute and relative cases $(a, r)$ was divided by 2 , and each numerical value was added to either the absolute cases or the relative cases.

Although the individual difference was great and the fish seemed in some cases to choose the figure by temperament, the general tendency of relative selection at first and of absolute selection later on with the progress of further training can hardly be denied.

\section{Interpretation}

When such a fish as Microcanthus strigatus, whose minimal visual angle is $4^{\prime} 23^{\prime \prime}$, approaches a fishing line of $0.08 \mathrm{~mm}$ in diameter, the drail would be just found by fish at the distance of $6.3 \mathrm{~cm}$ if the drail is dark colored and non-transparent. If the fish has just found the drail at $x \mathrm{~cm}$ from it, $x$ can be calculated as follows:

$0.08 \mathrm{~mm} / x \mathrm{~cm}=\operatorname{tg} 4^{\prime} 23^{\prime \prime}=0.001275$, then $x=0.08 \mathrm{~mm} / 0.001275=6.3 \mathrm{~cm}$. The visual angle of the drail at $5 \mathrm{~cm}$ distance is $0.08 \mathrm{~mm} / 5 \mathrm{~mm}=0.0016$ or $5^{\prime} 30^{\prime \prime}$. The fish whose minimum separabile is $4^{\prime} 23^{\prime \prime}$ can easily find such a drail at $5 \mathrm{~cm}$. To make a fishing line invisible to fish sight, man has by traditional experience devised fine, colorless and transparent fishing lines. On the other hand easily visible thick threads or sticks are used for fish weir, traps and barrier so as to let fish swim to a definite direction or place.

When such a fish having lesser visual acuity than $M$. strigatus (minimum separab. $4^{\prime} 23^{\prime \prime}$ ), for instance, Phoxinus laevis (minimum separab. 11') approaches the finest drail of $0.08 \mathrm{~mm}$ in diameter, the fish would scarcely perceive the drail even if it were colored and non-transparent, for the reason as such that the minimal visual angle of $11^{\prime}$ is reached first at the distance of $2.5 \mathrm{~cm}$ from the drail and that at such a short distance no clear image of an object would be formed on the retina of fish.

The curve indicating the relation between visual acuity and light intensity in man is sigmoid-formed (Fig. $10 \mathrm{I}$, KöNIG, 1897). That of Microcanthus strigatus is continuous double sigmoid-formed Fig. 4, Fig. $10 \mathrm{III})$. That of Phoxinus laevis shows a brick point at low light intensity with a steep curve directed downward from it (Fig. $10 \mathrm{II}$, BRUNNer 1934). The double sigmoid form of visual acuity curve plotted in Fig. 4 and Fig. $10 \mathrm{III}$ represents without doubt the functional difference of rods and cones in night and day vision of fish, as already pointed out by FrISCH (1924). 
I Man

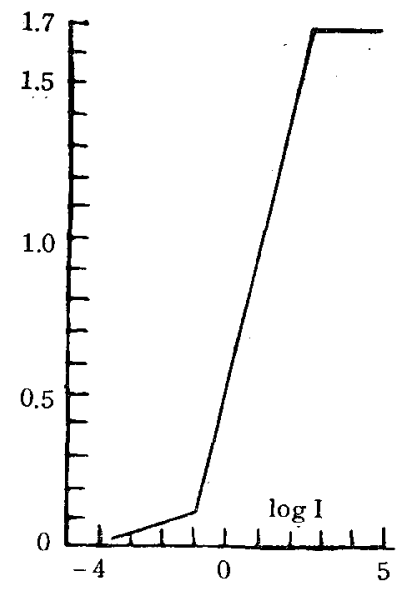

II Phoxinus

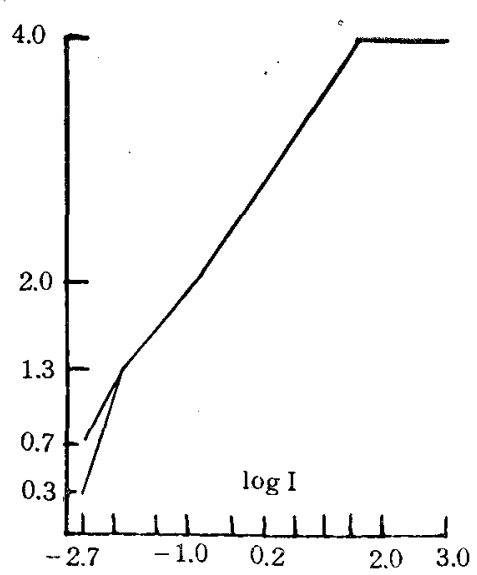

III Microcanthus

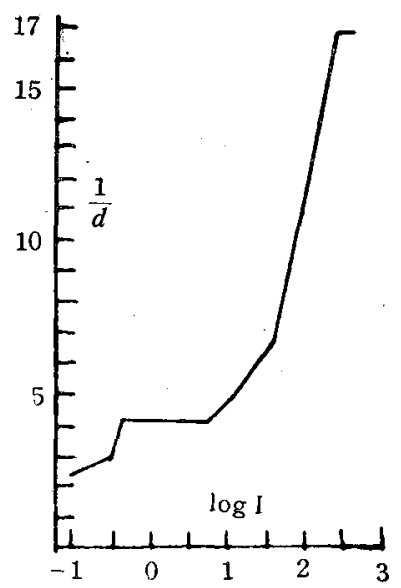

Fig. 10. Visual acuity curve under different illuminations. Ordinate-value of visual acuity, abscissa-- $\log$ of Lux. I after KöNIG 1897, II after BRUNNER 1934, III deformed from Fig. 4.

Table 15. The site of transition of the function between rods and cones.

\begin{tabular}{|c|c|c|}
\hline Animal & Site of transition & Author \\
\hline $\begin{array}{l}\text { man } \\
\text { Rana temporaria } \\
\text { sword-tail } \\
\text { Phoxinus laevis } \\
\text { Microcanthus strigatus }\end{array}$ & $\begin{array}{l}0.03 \ldots 0.1 \text { Lux } \\
0.1 \ldots \ldots 1 \text { Photon } \\
\quad \text { about } 2 \text { Lux } \\
0.1 \ldots \ldots 1 \text { Milliambert } \\
0.002 \ldots 0.008 \text { Lux } \\
0.4 \ldots . .5 \text { Lux }\end{array}$ & $\begin{array}{l}\text { KÖNIG } 1897 \\
\text { HECHT et WOLF (after BUDDENBROCK 1952) } \\
\text { BIRUKOW } 1937 \\
\text { CROZIER et WOLF } 1938 \\
\text { BRUNNER } 1934 \\
\text { in this work }\end{array}$ \\
\hline
\end{tabular}

Table 16. Minimal morphological and physiological visual angle of different animals.

\begin{tabular}{|c|c|c|c|}
\hline Animal & $\begin{array}{c}\text { Minimal } \\
\text { morpholog. } \\
\text { visual angle }\end{array}$ & $\begin{array}{c}\text { Minimal } \\
\text { physiolog. } \\
\text { visual angle }\end{array}$ & Author \\
\hline man & $18.5-74^{\prime \prime}$ & $23.3-64^{\prime \prime}$ & after BIRUKOW 1937 \\
\hline & - & $30-57^{\prime}$ & LASHLEY 1932 \\
\hline lizard (area) & $3^{\prime} 06^{\prime \prime}$ & - & EHRENHARDT 1937 \\
\hline (periphery) & $12^{\prime} 07^{\prime \prime}$ & $11^{\prime} 28^{\prime \prime}$ & \\
\hline pigeon & -...- & $2.7-3.1^{\prime}$ & HAMILTON 1933 \\
\hline game cock & -- & $3.1 \cdots 4^{\prime}$ & JOHNSON 1914 \\
\hline Rana temporaria & $6^{\prime} 48^{\prime \prime}$ & $6^{\prime} 53^{\prime \prime}$ & BIRUKOW 1937 \\
\hline Phoxinus laevis & $11^{\prime}$ & $11^{\prime}$ & BRUNNER 1934 \\
\hline Microcanthus strigatus & $3^{\prime} 36^{\prime \prime}$ & $\begin{array}{c}4^{\prime} 23^{\prime \prime}-6^{\prime} 35^{\prime \prime} \\
\text { average } 4^{\prime} 59^{\prime \prime}\end{array}$ & in this work \\
\hline honey bee & $1^{\circ}$ & $1^{\circ}$ & HECHT et WOLF 1929 \\
\hline Drosophila & $4^{\circ}$ & $4^{\circ}$ & GRAVEL (after BIRUKow 1937) \\
\hline & $4^{\circ}$ & $9.28^{\circ}$ & НЕСНT et WALD 1934 \\
\hline hermit-crab & $1.75-3^{\circ}$ & $4.2^{\circ}$ & BRÖCKER 1935 \\
\hline Uca pugnax & $2.05^{\circ}$ & $3.87^{\circ}$ & CLARK 1935 \\
\hline
\end{tabular}


Visual acuity increases in proportion to the size of eye, and is inversely proportional to the distance of each cone. Let $S m$ and $S p$ denote visual acuity of Microcanthus and Phoxinus respectively, and $d m, d p$ the cone distance in $\mu$, and $M m, M p$ the length of eye axis respectively ( $d p=6.25 \mu$ BRUNNER 1934), then

$$
\frac{S m}{S p}=\frac{M m}{d m} \cdot \frac{d p}{M p}=\frac{8 \mathrm{~mm}}{8.4 \mu} \frac{6.25 \mu}{2 \mathrm{~mm}}=2.93
$$

When visual acuity is compared in term of minimal morphological visual angle $\left(\omega^{\prime} m, \omega^{\prime} p\right)$, then

$$
\frac{\omega^{\prime} p}{\omega^{\prime} m}=\frac{11^{\prime}}{3^{\prime} 36^{\prime \prime}}=\frac{11^{\prime}}{3.60^{\prime}}=3.05
$$

When minimal physiological visual angle is compared,

then

$$
\frac{\omega p}{\omega m}=\frac{11^{\prime}}{4^{\prime} 23^{\prime \prime}}=\frac{11^{\prime}}{4.38^{\prime}}=2.51
$$

Minimal morphological visual angle should be theoretically smaller than the minimal physiological visual angle, as the incident light refracts strongly in the eye medium. Minimal morphological visual angle (11') given by BRunner (1934) for Phoxinus laevis seems to be too high in comparison with minimum separabile (11') from the above consideration. From (10) $\omega^{\prime}=\frac{n_{1}}{n_{2}} \omega$, then when $n_{1}=1.333$ (for fresh water) and $n_{2}=1.668$ (from Table 5).

$$
\omega^{\prime}=\frac{1.333}{1.668} \cdot 11^{\prime}=8.80^{\prime}, \quad \omega^{\prime} p / \omega^{\prime} m=8.80^{\prime} / 3.60^{\prime}=2.44
$$

This value does not seem to be very far from 2.51 .

From these comparisons, Microcanthus strigatus seems to have a 2 or 3 times keener vision than Phoximus laevis as the eye size of both fishes suggests $(M m / M p$ $=8 \mathrm{~mm} / 2 \mathrm{~mm}$ ). In short, the difference in visual acuity between the two species of fish has been reasonably explained from the physiological and morphological points of view.

The following numerical values were found in Microcanthus strigatus of $10-11 \mathrm{~cm}$ in size :

$\omega$, minimal physiological visual angle $4^{\prime} 23^{\prime \prime}$

$\omega_{1}^{\prime}$, minimal morphological visual angle deduced from (1) $3^{\prime} 30^{\prime \prime}$

$\omega_{2}^{\prime}$, minimal morphological visual angle calculated from measurement $3^{\prime} 36^{\prime \prime} \cdots(12)$

$d_{1}$, mean distance of cones calculated from measurement $8.4 \mu \cdots \ldots \ldots \ldots \ldots \ldots(7)$

$d_{2}$, mean distance of cones calculated from experimental data $8.2 \mu$

$m_{1}$, length of the eye axis measured $7.6-8.4 \mathrm{~mm}$ in average $8.0 \mathrm{~mm}$

$m_{2}$, length of the eye axis calculated from $m=F+r=3.54 r=8.0 \mathrm{~mm}$ (Table 11) though there is a small discrepancy in numerical value between $\omega_{1}^{\prime}$ and $\omega_{2}^{\prime}$, and also between $d_{1}$ and $d_{2}$, the general tendency of coincidence in paired values calculated or measured independently of each other can hardly be denied. The total lens refraction index $\left(n_{2}=1.668\right)$ should be estimated as the proper value for marine fish on account 
of the coincidence of the directly measured eye axis length with that of the calculated.

In some fishes the existence of Fovea has been demonstrated, for instance in Siphonostomum typhle and in Hippocampus hochgradig (OPPEL 1914, p. 73). $M$. strigatus has no clear Fovea, but in its retina there is the region of densely populated cones in the central and adjacent backward (outer) part of the retina surrounding processus falciformis (Fig. 7). This region would be estimated as actual Fovea. The adequacy of such microstructural differentiation in the retina has already been touched in the chapter III.

The visual acuity of fish is directly related with the net work of visual cells in the retina, and is not necessarily directly related with the distribution of ganglion cells as BRUNNer (1934) pointed out. Notwithstanding of this, there is, however, a close relationship between cones and ganglion cells so that in the actual foveal region of the retina the number of ganglions pro cone is highest in comparison with other regions of the retina (Table 10). Therefore it may be concluded that the visual acuity of fish is closely, though not directly, related with the distribution of ganglion cells.

Herter (1929) has demonstrated the relative selection in figural transposition in Phoxinus laevis by training the fish to the series of grey paper. Mörmann (1934) was of the opinion that honey bee selected figures in relative direction in light and dark shade training, when training number was in medium, and that the honey bee had the tendency to select the figure absolutely when the training was continued many times. Microcanthus strigatus exhibited, however obscure, the same attitude towards figural transposition (Table 14) as honey bee, though in the former case striped patterns were used as the training figure.

\section{Summary}

1. The minimal width of striation of a striped pattern discriminated by the coral fish Microcanthus strigatus of $10-11 \mathrm{~cm}$ in body length, were $0.051-0.077 \mathrm{~mm}$, in average $0.058 \mathrm{~mm}$. 3 fishes among 4 discriminatcd $0.051 \mathrm{~mm}$ width in bright light. The visual angle of these widths seen at $4 \mathrm{~cm}$ from the figures were $4^{\prime} 23^{\prime \prime}-6^{\prime} 35^{\prime \prime}$, in average $4^{\prime} 59^{\prime \prime}$ respectively. The fish was able to discriminate the striped pattern at $4 \mathrm{~cm}$ from the figures relatively independently of the width of striation.

2. The visual acuity curve plotted against the $\log$ of illumination (Lux) exhibited a continuous double sigmoid form. The functional difference between rods and cones in day and night vision has been clearly demonstrated by this curve.

3. The total refraction index of spherical lens of fish was calculated $\left(n_{2}=1.668\right)$ from $n_{2}=\frac{2.678(m-r)}{2 m-3 r}$ by the measurement of the lens diameter $(2 r)$ and the length of eye axis $(m)$.

4. The mean distance of two adjacent cones was calculated by counting the number of cones in a definite area $(93 \times 93 \mu)$, and was estimated as $8.4 \mu$ in fishes of 
$10-11 \mathrm{~cm}$ body length. The density of cones was highest at the central and adjacent back part of the retina surrounding process falciformis. This region actually seems to be a Fovea, though no clear one could be found morphologically. In this region ganglion cells were more dense than in the other parts of the retina considering the ratio between the number of ganglion cells and the number of cones.

5. The mean distance of cones in the actual foveal area derived from the minimal physiological visual angle was $8.2 \mu$ which coincided practically with $8.4 \mu$ found independently by the measurement of cone distribution in the retina.

6. The minimal morphological visual angle calculated from minimal physiological visual angle was $3^{\prime} 30^{\prime \prime}$, whereas that of morphologically found by measuring the mean cone distance and the length of eye axis was $3^{\prime} 36^{\prime \prime}$.

7. The change in visual acuity was computated by calculating the visual acuity from the size of lens and mean distance of cones in the retina. The relative visual acuity increased with the growth of fish and approached a constant level when the fish size became $10 \mathrm{~cm}$ in length.

8. During the training of fish to vertically striped patterns of different fineness, the selection of test figures by fish was made at first to relative direction in the test of figural transposition, and later an absolute selection surpassed the relative one.

9. The reason why in angling a fine, colorless and transparent fishing line is commonly used, is made clear, and also the differences in visual acuity between fishes with large eyes and those with small ones was discussed on the basis of optical data.

\section{Acknowledgment}

The author wishes to express his sincere gratitude to the Director of the Laboratory, Prof. D. Miyadi, for his kind guidance and encouragement.

\section{LITERATURE CITED}

BIRUKow, G. 1937. Untersuchungen über den optischen Drehnystagmus und über die Sehschärfe des Grasfrosches (Rana temporaria). Z. vergl. Physiol., Bd. 25, p. 92.

BRöCKER, H. 1935. Untersuchungen ïber das Sehvermögen der Einsiedlerkrebse. Zool Jahrb. Allg. Bd. 55.

BRUNNER, G. 1934. Ueber dis Sehschärfe der Erlitze (Phoxinus laevis) bei verschiedenen Helligkeiten. Z. verg1 Physiol., Bd. 21, p. 296.

Buddenbrock, W. von 1952. Vergleichende Physiologie. Bd. I. Sinnesphysiologie. Basel. pp. 120, 192.

ClAARK, L. B. 1935. The visual acuity of the fidder-crab Uca pugnax. J. gen. Physiol., vol. 19. Crozier, W. J., Wolf, E. E. and Wolf, G. Z. 1938. Critical illumination and flicker frequency in related fishes. J, gen. Physiol, vol. 21, p. 17.

EHRENHARDT, H. 1937. Formensehen und Sehschärfebestimmungen bei Eidechse. Z. vergl. Physiol., Bd. 24, p. 248.

FrIscr, K. von 1924. Farbensinn der Erlitze und Duplizitätstheorie. Z. vergl. Physiol., Bd. 2. 
Hamilton, W. F. and Goldstein. 1933. Visual acuity and accomodation in the pigeon. J. comp. Psychol., vol. 15.

HECHT, S. and WALD, G. 1934. The visual acuity and intensity discrimination of Drosophila. J. gen. Physiol., vol. 20.

Hecht, S. and Wolf, E. 1929. The visual acuity of the honey bee. J. gen. Physiol., vol. 12, p. 727. Herter, K. 1929. Dressurversuche an Fischen. Z. vergl. Physiol, Bd. 10. 1930. Weitere Dressurversuche an Fischen. Ibid. Bd. 11.

Hörmann, M. 1934. Ueber den Helligkeitsinn der Bienen. Z. vergl. Physiol., B1. 21, p. 188.

Houstoun, R. A. 1924. A treatise on light. London. p. 44.

JoHnSon. 1914. Visual pattern-discrimination in vertebrates. II. J. Animal Behavior, vol. 4, p. 340.

KÖNIG, A. 1897. Die Abhängigkeit der Sehschärfe von der Beleuchtungsintänsität. Sitzber. Akad. Wiss. Berlin.

Matthiessen, L. 1886. Ueber den physikalisch-optischen Bau des Auges der Cetaceen und der Fische. Pflüger's Archiv, Bd. 38, p. 521.

Oppei, A. 1913. Lehrbuch der vergleichenden mikroskopischen Anatomie der Wirbeltiere, p. 72.

LASHLEY. 1932. The mechanism of vision. V. Structure and image forming power of rat's eye. J. comp. Psychol., vol. 13, p. 173.

Yamanouchi, T. 1936. The visual acuity of fish. (in Japanese). Zool. Mag., vol, 48, p. 203. 